\title{
Phytoremediation potential of water hyacinth (Eichhornia crassipes) for phenol and cyanide elimination from synthetic/simulated wastewater
}

\author{
Neetu Singh ${ }^{1} \cdot$ Chandrajit Balomajumder $^{1}$
}

Received: 21 December 2016 / Accepted: 14 July 2021 / Published online: 27 July 2021

(c) The Author(s) 2021

\begin{abstract}
Water pollution is increasing due to urbanization and industrialization. Waste water pollution raised concern because of its influence on plants and humans. Water hyacinth (Eichhornia crassipes) is used for the removal of pollutants because of its phytoremediation efficiency. In this study, water hyacinth (Eichhornia crassipes) has been tested for simultaneous elimination of phenol and cyanide from mono and binary component aqueous solution in batch systems. The plant was grown at six concentrations of phenol and cyanide in the ratio of (10:1), i.e. 100:10, 200:20, 300:30, 500:50, 700:70 and 1000:100 mg/L in aqueous solution. The effect of process parameters such as initial concentration of phenol and cyanide and $\mathrm{pH}$ was evaluated. The plant was found capable of eliminating up to $96.42 \%$ of phenol $(300 \mathrm{mg} / \mathrm{L})$ and $92.66 \%$ of cyanide $(30 \mathrm{mg} / \mathrm{L})$ during the 13 days cultivation time at $\mathrm{pH}$ 8. The calculated $K_{\mathrm{m}}$ of the root length elongation for phenol was $5.20 \mathrm{~mm}$ and the $V_{\max }$ was $12.52 \mu \mathrm{g} \mathrm{phenol} / \mathrm{g}$ root/h. However, the calculated $K_{\mathrm{m}}$ of the root length elongation for cyanide was $0.39 \mathrm{~mm}$ and the $V_{\max }$ was $14.99 \mu \mathrm{g}$ cyanide/g root/h. In the Eichhornia crassipes plant, the biochemical parameters such as chlorophyll, protein and sugar content have been indicated a decreasing trend due to uptake of phenol and cyanide throughout cultivation. Toxicity to $100-1000 \mathrm{mg} / \mathrm{L}$ of phenol and $10-100 \mathrm{mg} / \mathrm{L}$ of cyanide was measured by measuring the relative transpiration over 13 days. At $100 \mathrm{mg} / \mathrm{L}$ of phenol and $10 \mathrm{mg} / \mathrm{L}$ of cyanide, only a small reduction in transpiration but no morphological changes were noticed. Both pollutants are absorbed through the root of the Eichhornia crassipes plant by plasmalemma and become accumulated into the root cells and stem of a plant. Thus, this study will be beneficial for the decontamination of highly polluted waste water.
\end{abstract}

Keywords Accumulation $\cdot$ Cyanide $\cdot$ Eichhornia crassipes $\cdot$ Normalized relative transpiration $\cdot$ Phenol $\cdot$ Phytoremediation

\section{Introduction}

Water is one of the furthermost significant natural resources, necessary for all forms of life. This water resource is being polluted by several anthropogenic actions such as rapid growth of urbanization, industrialization and populations that finally make the environment polluted (Singh and Balomajumder 2016). Phenol and cyanide pollution signifies an important environmental problem due to toxic effects of

Neetu Singh

neeturbs@gmail.com

Chandrajit Balomajumder

chandfch@iitr.ernet.in

1 Department of Chemical Engineering, Indian Institute of Technology, Roorkee, India pollutants, their resistance and subsequent determination (Busca et al. 2008; Dash et al. 2014). It is difficult to predict the features of steel plant wastewater by stated values in the literature as every industry is sole in respect to the manufacture, technology and chemicals used. The steel plant wastewater is categorized as the most contaminating among all in the industrial sectors (Marano'n et al. 2008; Staib and Lant 2007). The steel plant wastewater is a complex and variable mixture of polluting substances like organic and inorganic elemental products (Maran ón et al. 2008). Among complex steel plant wastewater with several types of polluting substances, phenol and cyanide wastes are major. US Environmental Protection Agency (US EPA) and minimal national standard (MINAS) of central pollution control board (CPCB) limit for cyanide in effluent as $0.2 \mathrm{mg} / \mathrm{L}$ and for phenol as $0.5 \mathrm{mg} / \mathrm{L}$ (Busca et al. 2008; Dash et al. 2014). Therefore, it is important the removal of both compounds 
for letting down the concentrations to below under regulatory limits.

There are several treatment methods employed for the wastewater like reverse osmosis, adsorption, ion exchange, leaching, oxidization, precipitation, biodegradation, solvent extraction, etc. (Akcil 2003; Vedula et al. 2013). The above mentioned physicochemical processes for treatment had thoughtful limitations, so it has become essential to look for substitute and environment friendly treatment methods. In current years, phytoremediation, which was well-defined as the use of green plants to reduce organic and inorganic environmental pollutants (Hejna et al. 2020; Mahalakshmi et al. 2019a; Cunningham and Ow 1996; Yadav et al. 2018), has been accepted as a cheap and eco-friendly alternative treatment technology. Aquatic plant-based cost-effective treatment technologies can be approved by emerging countries for wastewater. Furthermore, it has many advantages in comparison with other treatment methods (Shi et al. 2020; Abbas et al. 2019; Daud et al. 2018; Gerhardt 2017; Leguizamo et al. 2017; Rezania et al. 2015; Pilon-Smits 2005; Yadav et al. 2018). To make the phytoremediation and ecofriendly technology, plants should have the subsequent characteristics such as quick growth rate, high biomass yield, the uptake of a large amount of pollutants, the capacity to transport pollutants in aboveground parts of plant, and a mechanism to tolerate pollutants toxicity (Ali et al. 2013; Arslan et al. 2017; Burges et al. 2018; Cunningham and Ow 1996; Rezania et al. 2015b). Other factors like $\mathrm{pH}$, nutrient availability and salinity highly effect the phytoremediation potential and plant growth (Rezania et al. 2015c; Reeves et al. 2018 and Tewes et al. 2018; Yadav et al. 2018). Pollutants bind to efficient sites on the surface of the roots, a process that is additional enhanced by the accumulation of pollutants in the roots and the transfer to other parts of plant. Among several plants for phytoremediation, water hyacinth (Eichhornia crassipes) is used for the removal of pollutants because of its capability to grow in highly polluted water (Mahalakshmi et al. 2019b; Sarkar 2017; Ebel et al. 2007; Roy and Hanninen 1994). Eichhornia crassipes can bear significant variation in nutrients, $\mathrm{pH}$ levels (optimum growth at $6-8 \mathrm{pH}$ ) and temperatures (from 1 to $40{ }^{\circ} \mathrm{C}$, optimum growth at $25-30{ }^{\circ} \mathrm{C}$ ). The pollutant removal from wastewater comprises both fast and slow mechanisms, whose influence differs for different pollutants. The major characteristics of Eichhornia crassipes are their rapid growth rate with extensive root system, not serving as food for animal or humans, and informal control of their population by eliminating the antagonistically spreading parts, which could even be collected and refined as a renewable source of bioenergy (Wilkie and Evans 2010).

Therefore, the main aim of present study is to evaluate (i) the efficiency of floating aquatic plant, Eichhornia crassipes, for the removal of phenol and cyanide (ii) The effects of process parameters (initial concentration, $\mathrm{pH}$, and biochemical parameters) on phenol and cyanide removal. The normalized relative transpiration (NRT) and Michaelis-Menten kinetic parameters were analyzed.

\section{Materials and methods}

\section{Chemicals and reagents}

All the chemicals used in this study were obtained from Himedia Laboratories Pvt. Ltd. Mumbai, India. Synthetic/ simulated phenol and cyanide solution was prepared and diluted with double distilled water for preparation of different concentration. Stock solutions of phenol and cyanide were obtained by dissolving the appropriate quantities of phenol and sodium cyanide, in $1 \mathrm{~L}$ of millipore water (Q-H2O, Millipore Corp. with resistivity of $18.2 \mathrm{MX}-\mathrm{cm}$ ), respectively. Stock solution containing $100 \mathrm{mg} / \mathrm{L}$ cyanide was prepared by dissolving $0.0189 \mathrm{~g}$ of $\mathrm{NaCN}$ and stock solution comprising $1000 \mathrm{mg} / \mathrm{L}$ of phenol was prepared by dissolving $1 \mathrm{~g}$ of pure phenol crystal in $1 \mathrm{~L}$ of millipore water. The concentrations of phenol was varies $(100-1000$ $\mathrm{mg} / \mathrm{L})$ and cyanide varies $(10-100 \mathrm{mg} / \mathrm{L})$.

\section{Experimental setup for study}

Eichhornia crassipes was obtained from Solani River Roorkee, India from the stationary water body and cleaned using floating tap water and put in the 5\% Hoagland's nutrient solution for experiment (Hoagland and Arnon 1950). The plants were used with the similar weight and size and 5-6 weeks old and placed in container for test. The study was accompanied in seven plastic pots, installed in artificial photosynthesis chamber at the Indian Institute of Technology Roorkee, India.

The plants were grown with controlled operating conditions $45 \mu \mathrm{mol} / \mathrm{m}^{2} \mathrm{~s}^{1}$ photon flux intensity and $60 \%$ relative humidity at $30 \pm 1{ }^{\circ} \mathrm{C}$. Eichhornia crassipes plants were grown in $1 \mathrm{~L}$ experimental pots filled with $900 \mathrm{~mL}$ Hoagland nutrient solution and kept in phytoremediation chamber. In phytoremediation chamber, artificial light was delivered for all plants with a light period of $12 \mathrm{~h}$ (light-on) and $12 \mathrm{~h}$ (light-off) maintained with fluorescent tube lights). The treatments were replicated three times; plant and water samples were collected from pots after 13 days cultivation for further study. The growth length of Eichhornia crassipes plant root and shoot was measured randomly with a ruler after every 4 days of culture to determine the effect on the physical health of the plant by phenol and cyanide concentration. In all studies, phenol at a concentration of $300 \mathrm{mg} / \mathrm{L}$ and cyanide concentration of $30 \mathrm{mg} / \mathrm{L}$ were used, excluding the effect of initial concentrations was tested. 


\section{Samples collection and physicochemical analysis}

To observe the remaining concentration of phenol and cyanide, water samples were collected aseptically periodically from all the pots at 13 days of treatments. Suspended particles were separated by filter paper. Phenol and cyanide were estimated by standard methods as defined in APHA (2001). The analysis of cyanide and phenol was carried out using a UV spectrophotometer (HACH DR 5000) by calorimetric picric acid with a wavelength $510 \mathrm{~nm}$ and 4-aminoantipyrene methods with a wavelength $520 \mathrm{~nm}$, respectively.

Surface morphology parts of plant were determined by using field emission scanning electron microscopy (FeSEM) and energy dispersive X-ray (EDX). Field emission scanning electron microscope (FE-SEM Quanta 200 FEG, FEI Netherlands) was used to determine the surface morphology and chemical composition of the element present on the surface of plant. Accumulation of protein, sugar and chlorophyll in roots, leaves and stem was determined by using digestion method (Dubois et al. 1956; Lowry et al. 1951; Maclachalam and Zalik 1963). For the estimation of accumulation of phenol and cyanide in different parts of the plant, the samples were crushed. These samples were digested with $\mathrm{HNO}_{3}-\mathrm{HClO}_{4}$ in 2:1 ratio (v/v) and diluted to $100 \mathrm{~mL}$ with millipore water (Dubois et al. 1956).

The removal capacity of cyanide and phenol was calculated by (Eq. 1):

$q_{m}=\left(c_{f}-c_{i}\right) \times v / w$

where

$q_{\mathrm{m}}$ is the plant removal capacity $(\mathrm{mg} / \mathrm{g})$, where $\mathrm{m}_{1}$ and $\mathrm{m}_{2}$ are the weight of the plant (Eichhornia crassipes) before uptake $\left(\mathrm{t}_{1}\right)$ and after uptake $\left(\mathrm{t}_{2}\right)$, respectively.

$c_{\mathrm{f}}$ is the final concentration of pollutants in plant and solution $(\mathrm{mg} / \mathrm{L})$, where $\mathrm{m}_{1}$ and $\mathrm{m}_{2}$ are the weight of the plant (Eichhornia crassipes) before uptake $\left(\mathrm{t}_{1}\right)$ and after uptake $\left(\mathrm{t}_{2}\right)$, respectively.

$c_{\mathrm{i}}$ is the initial concentration of pollutants in plant and solution $(\mathrm{mg} / \mathrm{L})$, where $\mathrm{m}_{1}$ and $\mathrm{m}_{2}$ are the weight of the plant (Eichhornia crassipes) before uptake $\left(\mathrm{t}_{1}\right)$ and after uptake $\left(\mathrm{t}_{2}\right)$, respectively.

$v$ is the volume of solution (L), where $\mathrm{m}_{1}$ and $\mathrm{m}_{2}$ are the weight of the plant (Eichhornia crassipes) before uptake $\left(\mathrm{t}_{1}\right)$ and after uptake $\left(\mathrm{t}_{2}\right)$, respectively.

$w$ is the fresh weight of plant $(\mathrm{g})$.

Relative growth rate (RGR) (Maine, 2001) $=\left(m_{2}-m_{1}\right) /\left(t_{2}-t_{1}\right)$

where $\mathrm{m}_{1}$ and $\mathrm{m}_{2}$ are the weight of the plant (Eichhornia crassipes) before uptake $\left(\mathrm{t}_{1}\right)$ and after uptake $\left(\mathrm{t}_{2}\right)$, respectively.
Bioconcentration factor (BCF) was considered for different parts of plant as root, stem, and leaves by the following equation:

Bioconcentration factor $(\mathrm{BCF})=C_{\mathrm{p}, \text { plant }} / C_{\mathrm{p}, \text { solution }}$

where $C_{\mathrm{p}, \text { plant }}$ is the pollutant concentration in the part of the plant ( $\mathrm{mg} / \mathrm{kg}$ ) and $C_{\mathrm{p} \text {,solution }}$ is the pollutant concentration in the solution $(\mathrm{mg} / \mathrm{L})$.

Translocation factor (TF) (Pandey 2012) for pollutants inside a plant was calculated by the given equation as:

Translocation factor(TF) $=C_{\mathrm{p}, \text { stem }} / C_{\mathrm{p}, \text { root }}$

where $C_{\mathrm{p}, \text { stem }}$ is the pollutants concentration in stem of plant and $C_{\mathrm{p}, \text { root }}$ is the pollutant concentration in root of plant.

The relationship between pollutant concentration $(C)$ and uptake rates $(V)$ was plotted and fitted to the equation proposed by Michaelis-Menten model (Roshani and Narayanasamy 2010).

$V=\left(V_{\max } \times C\right) /\left(K_{\mathrm{m}}+C\right)$

where $V$ is the rate of phenol and cyanide absorption when its concentration in solution is $C, V_{\max }$ is the maximum rate of phenol and cyanide uptake, $C$ is phenol and cyanide concentration in the uptake solution, and $K_{\mathrm{m}}$ is the Michaelis-Menten constant.

The mean normalized relative transpiration (NRT) is calculated by given equation.

$N R T(C, t)=\frac{1 / n \sum_{i=1}^{n} \frac{T_{i}(C, t)}{T_{i}(C, 0)}}{1 / m \sum_{i=m}^{m} \frac{T_{j}(0, t)}{T_{j}(0,0)}}$

where $C$ is the concentration of pollutants in $\mathrm{mg} / \mathrm{L}$, it is the time period in $\mathrm{h}$ till the end of the experiment, $\mathrm{T}$ is the absolute transpiration in $\mathrm{g} / \mathrm{h}$ and $\mathrm{i}$ is replicate $1,2, \ldots, \mathrm{n}$ and $\mathrm{j}$ is control $1,2, \ldots, \mathrm{m}$ for plants.

\section{Results and discussion}

\section{Characterization of Eichhornia crassipes plant}

\section{FTIR}

FTIR analysis of Eichhornia crassipes plant was carried out for leaves, stem and roots, before and after treatment of phenol and cyanide to determine the occurrence of functional groups on the surface of the plant as shown in Fig. 1a, b and c, for leaves, stem and roots, respectively.

It was observed from figures that the strong band is found around $3411.67 \mathrm{~cm}^{-1}$ in FTIR spectrum of leaves, root, and shoot of the Eichhornia crassipes, before uptake of phenol 
Fig. 1 a FTIR analysis of plant leaves: (i) Unloaded with phenol and cyanide and (ii) loaded with phenol and cyanide. $\mathbf{b}$

FTIR analysis of plant stem: (i) Unloaded with phenol and cyanide and (ii) loaded with phenol and cyanide. $\mathbf{c}$ FTIR analysis of plant root: (i) Unloaded with phenol and cyanide and (ii) loaded with phenol and cyanide
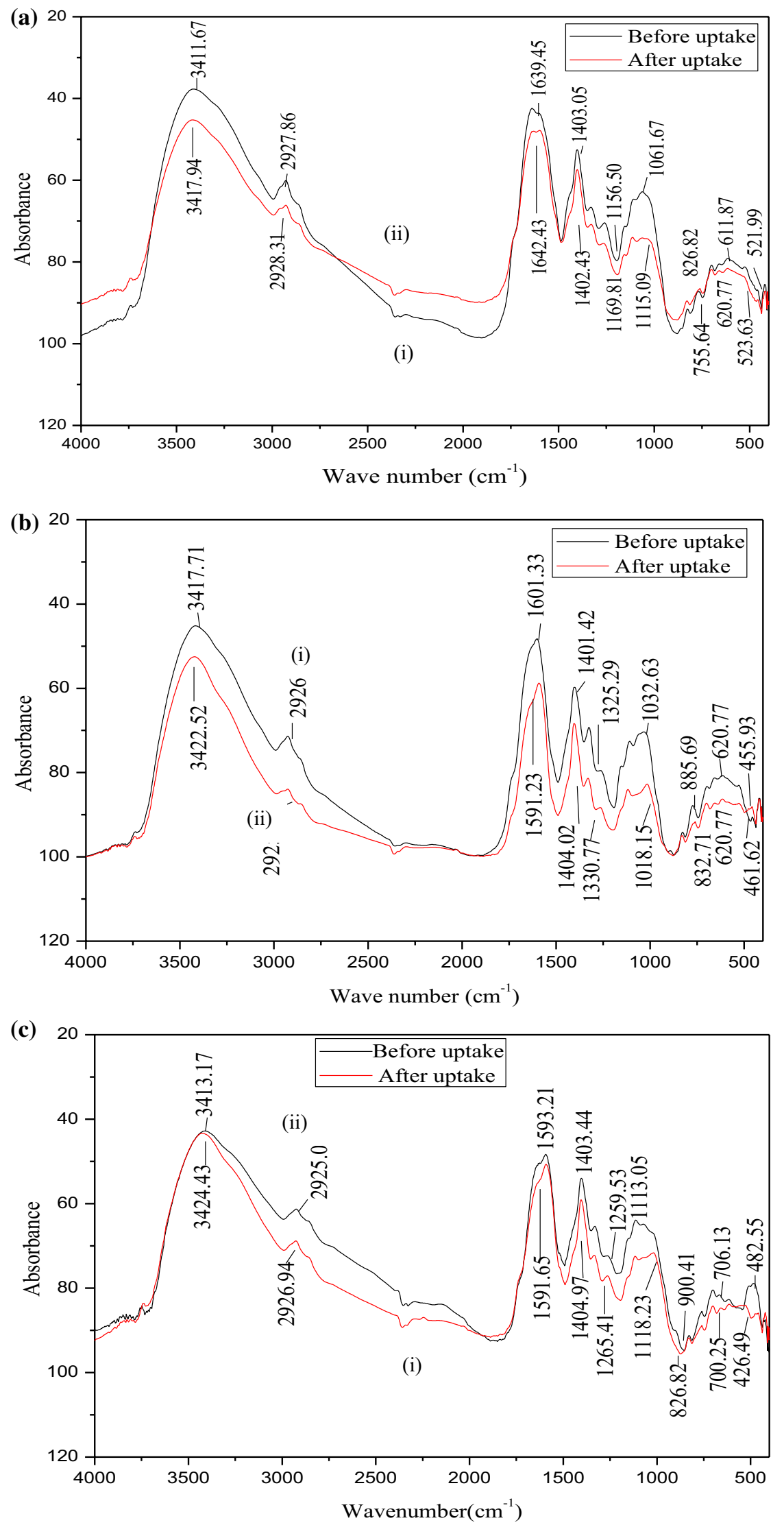
and cyanide due to the vibrations of $\mathrm{N}-\mathrm{H}$ and $\mathrm{O}-\mathrm{H}$ functional groups. The change was found in peak area around $\mathrm{N}-\mathrm{H}$ and $\mathrm{O}-\mathrm{H}$ functional group after uptake of phenol and cyanide. The peak around $2927.86 \mathrm{~cm}^{-1}$ due to $\mathrm{C}-\mathrm{H}$ group was found increase after the uptake of phenol and cyanide. Peak increase at $1639.45 \mathrm{~cm}^{-1}$ relates to $-\mathrm{CH}$ stretching owing to the occurrence of conjugated hydrocarbon groups, carboxylic groups, aromatic hydrocarbons, and carboxyl and carbonate structures representing uptake of phenol; however, peak at 1403.05 to $1156.50 \mathrm{~cm}^{-1}$ corresponds to inorganic nitrates marking a possible uptake site for cyanide. An increase in absorbance around peaks at $1403.05 \mathrm{~cm}^{-1}$ reveals the uptake of cyanide in the form of nitrates and amines. Further peak around $755.64 \mathrm{~cm}^{-1}$ relates to uptake of pollutants owing to the occurrence of methylene groups. In addition, the peak around $523.63 \mathrm{~cm}^{-1}$ to $1639.45 \mathrm{~cm}^{-1}$ in the FTIR spectrum of Eichhornia crassipes parts, i.e. leaves, stem, and roots, signifies the $\mathrm{C}-\mathrm{C}$ bond stretch. These shifts in the peaks indicated that there were pollutants binding process taking place at the surface of the plants. It could be observed from FTIR spectrum of Eichhornia crassipes that more uptake of pollutant was found in stem and roots than leaves.

\section{Fe-SEM analysis}

From the SEM micrographs (Figs. 2, 3 and 4), it is clearly seen that phenol and cyanide concentration has affected the structure of plant biomass. Phenol and cyanide loaded on the plant surface (Figs. 2b, 3b and $4 b$ ) revealed the formation of swollen texture with an accumulation of phenol and cyanide ions on the surface of leaves, stem and roots. This solid structure displays uptake of phenol and cyanide species
Fig. 2 a SEM analysis of Eichhornia crassipes leaves unloaded with phenol and cyanide and $\mathbf{b}$ loaded with phenol and cyanide (at a magnification of $1 \mathrm{~K}$ )

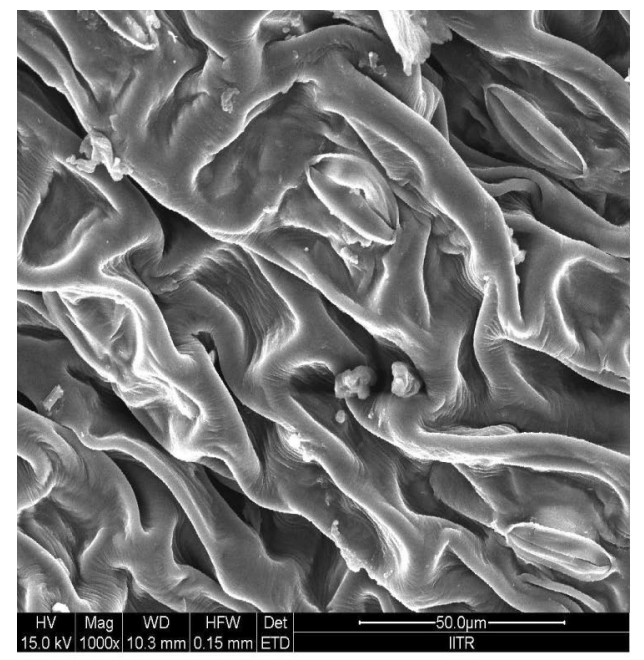

(a)

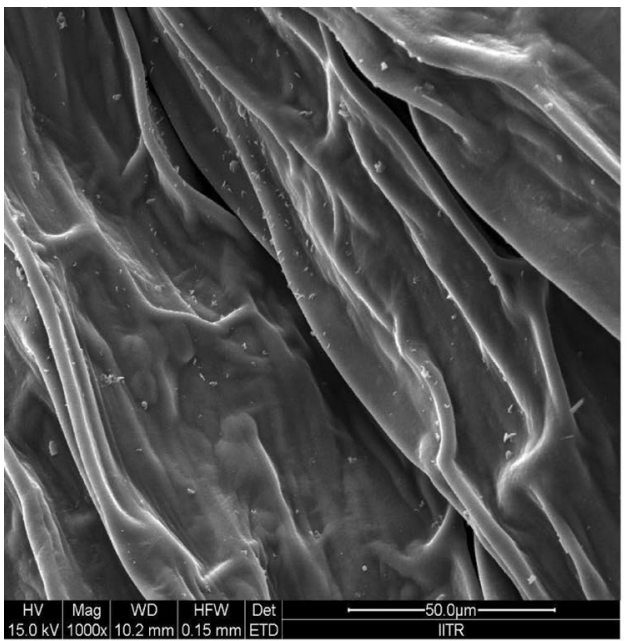

(a)

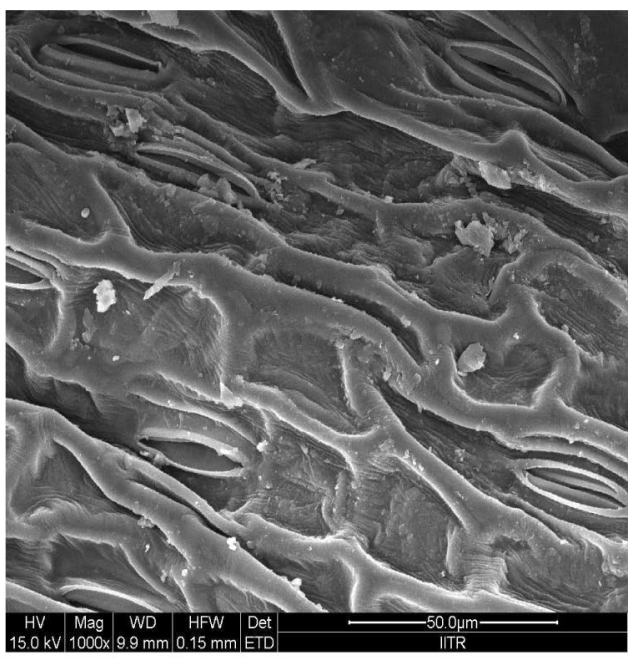

(b)
Fig. 3 a EM analysis of Eichhornia crassipes stem unloaded with phenol and cyanide and $\mathbf{b}$ loaded with phenol and cyanide (at a magnification of $1 \mathrm{~K}$ ) 
Fig. 4 a SEM analysis of Eichhornia crassipes roots unloaded with phenol and cyanide and $\mathbf{b}$ loaded with phenol and cyanide (at a magnification of $1 \mathrm{~K}$ )

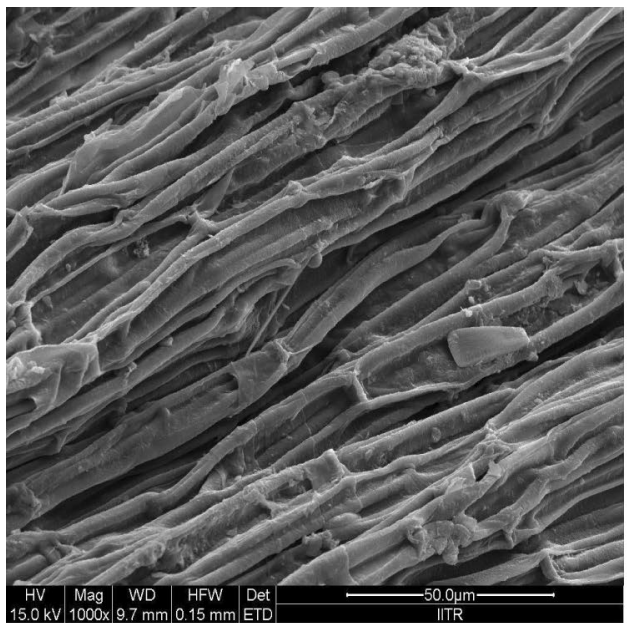

(a)

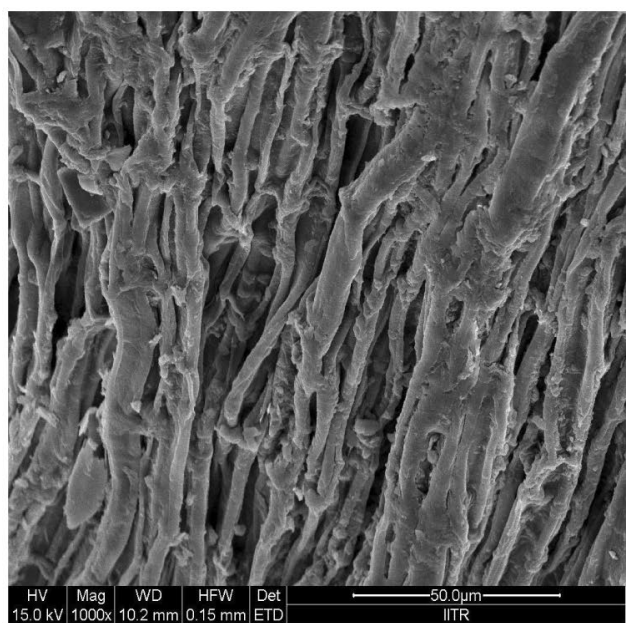

(b) by water hyacinth through small pores present on the surface of plant biomass from the liquid medium.

\section{EDX analysis}

EDX analysis was carried out to understand the presence of elements on the surface of water hyacinth plant before and after treatment of phenol and cyanide concentration at optimum condition. Figure 5( $\mathrm{a}$ and $\mathrm{b}$ ) shows the presence of $41.40 \%$ and $39.00 \%$ of carbon, $44.72 \%$ and $45.64 \%$ of oxygen, $0.00 \%$ and 0.31 sodium, $6.69 \%$ and $7.82 \%$ of potassium, $1.83 \%$ and $2.06 \%$ phosphorus in unloaded phenol and cyanide and loaded phenol and cyanide of the plant leaves, respectively. Figure 6( $\mathrm{a}$ and $\mathrm{b}$ ) shows the presence of $39.96 \%$ and $43.34 \%$ of carbon, $39.14 \%$ and $42.47 \%$ of oxygen, $14.9 \%$ and $11.65 \%$ of potassium, $2.50 \%$ and $2.83 \%$ phosphorus and $0.00 \%$ and $3.1 \%$ of nitrogen in unloaded phenol and cyanide and loaded phenol and cyanide of the plant steams, respectively. Similarly, the presence of elements on the surface of plant root Fig. 7(a and b) is as follow: $42.07 \%$ and $46.32 \%$ of carbon, $40.91 \%$ and $47.28 \%$ of oxygen, $0.00 \%$ and 0.63 sodium, $4.08 \%$

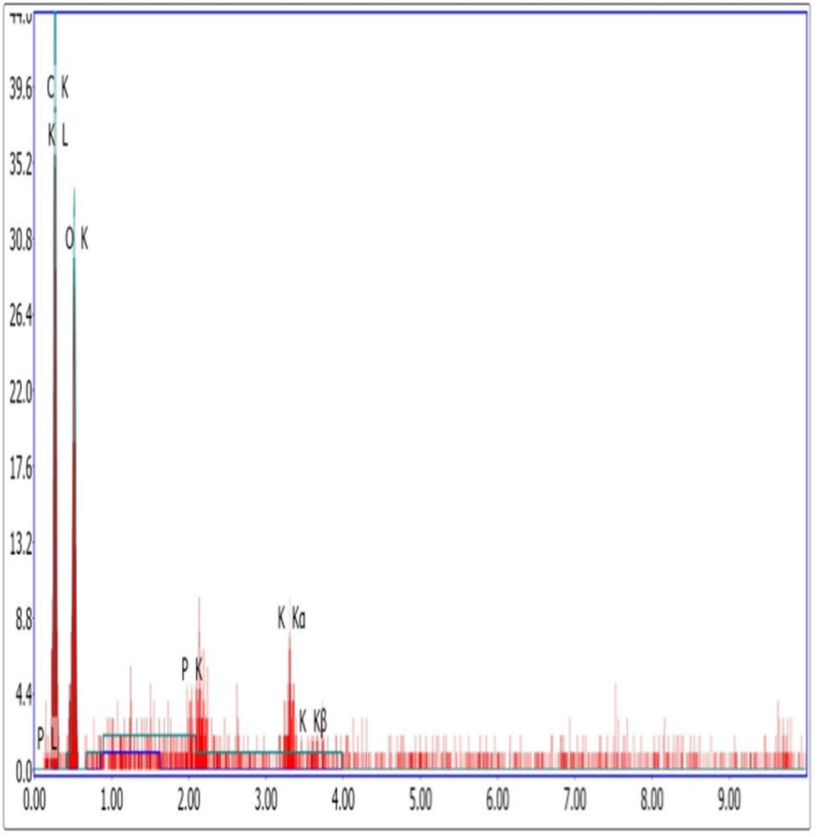

Les: 30.00 Cits 0.000 keV Det: Octane Pro Det Reso

(a)

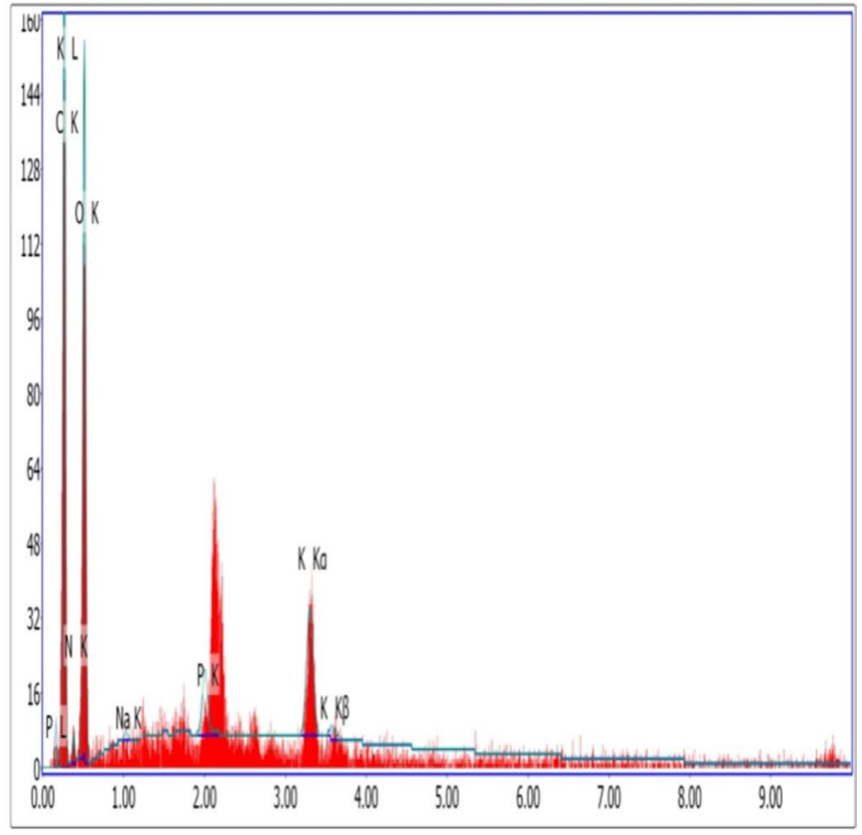

Lsec: 30.00 Cits 0.000 kel Det: Otane Pro Det Reso

(b)

Fig. 5 a EDX analysis of Eichhornia crassipes leaves unloaded with phenol and cyanide and b loaded with phenol and cyanide 


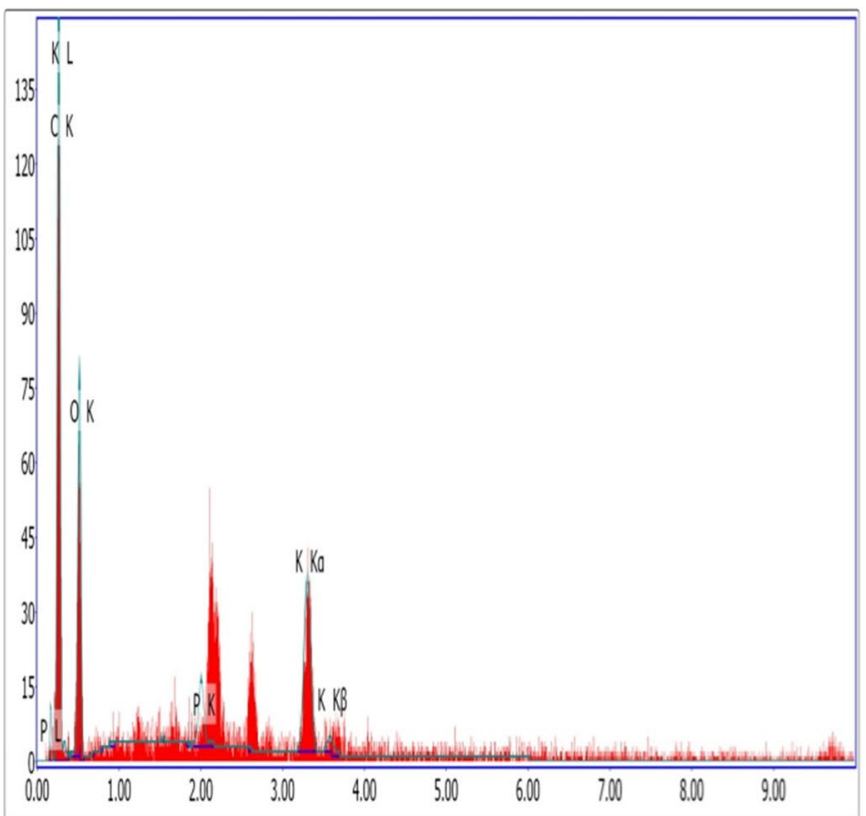

Lsec: 30.00 Cnts 0.000 keV Det: Octane Pro Det $\quad$ Reso

(a)

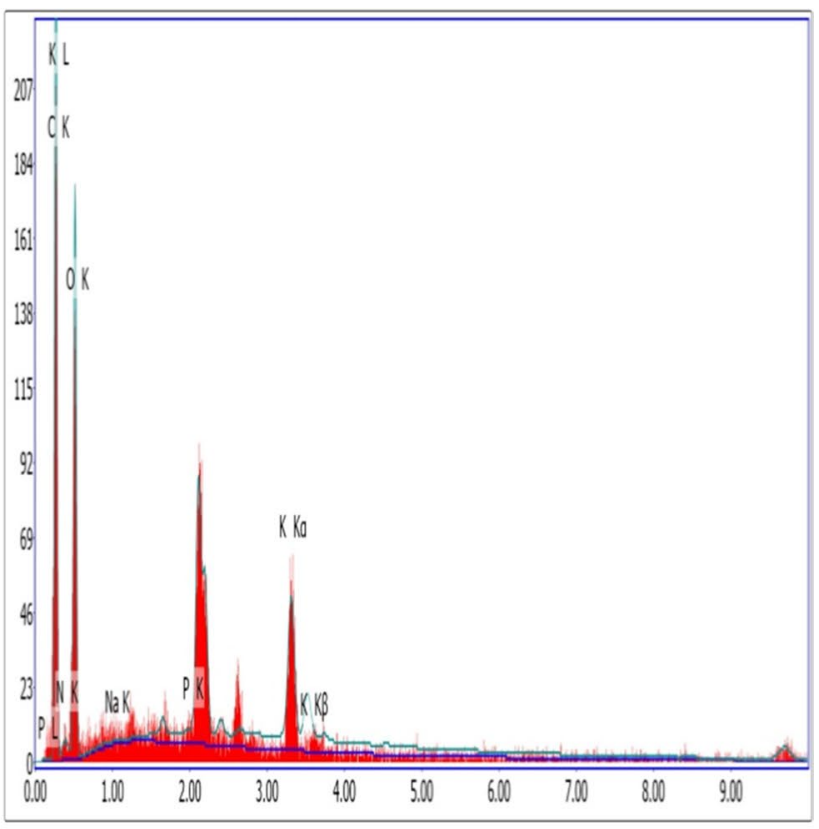

Lec: 30.00 Cits 0.000 kel Det: Otane Pro Det. Reso

(b)

Fig. 6 a EDX analysis of Eichhornia crassipes steam unloaded with phenol and cyanide and $\mathbf{b}$ loaded with phenol and cyanide

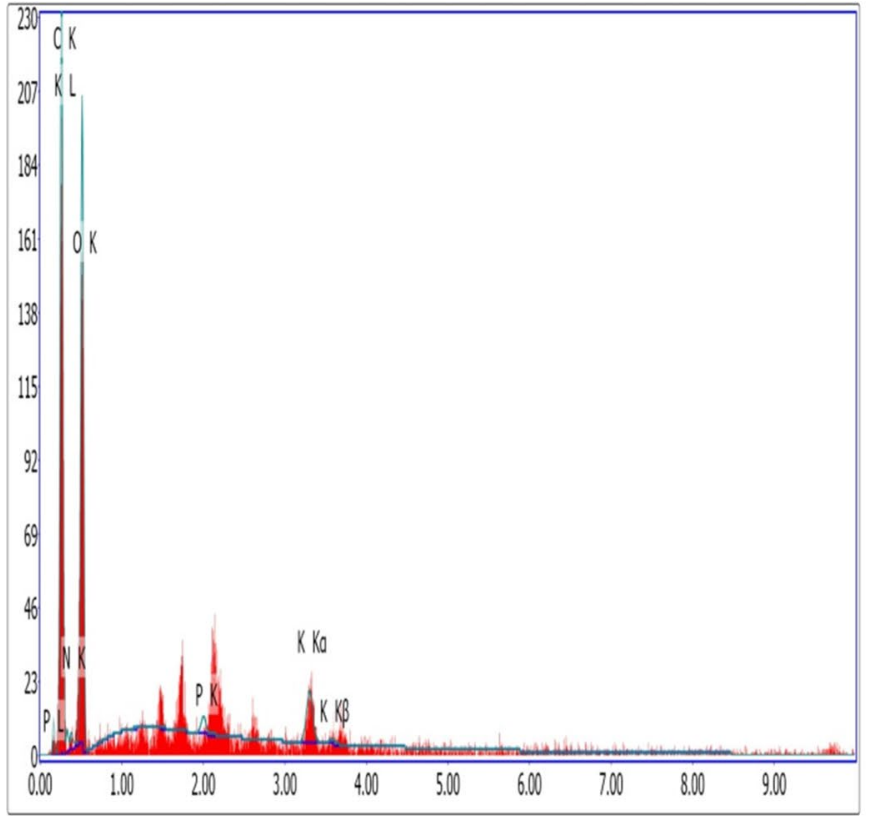

Leec: 30,00 Cits 0.000 keV Det: Ottane Pro Det Reso

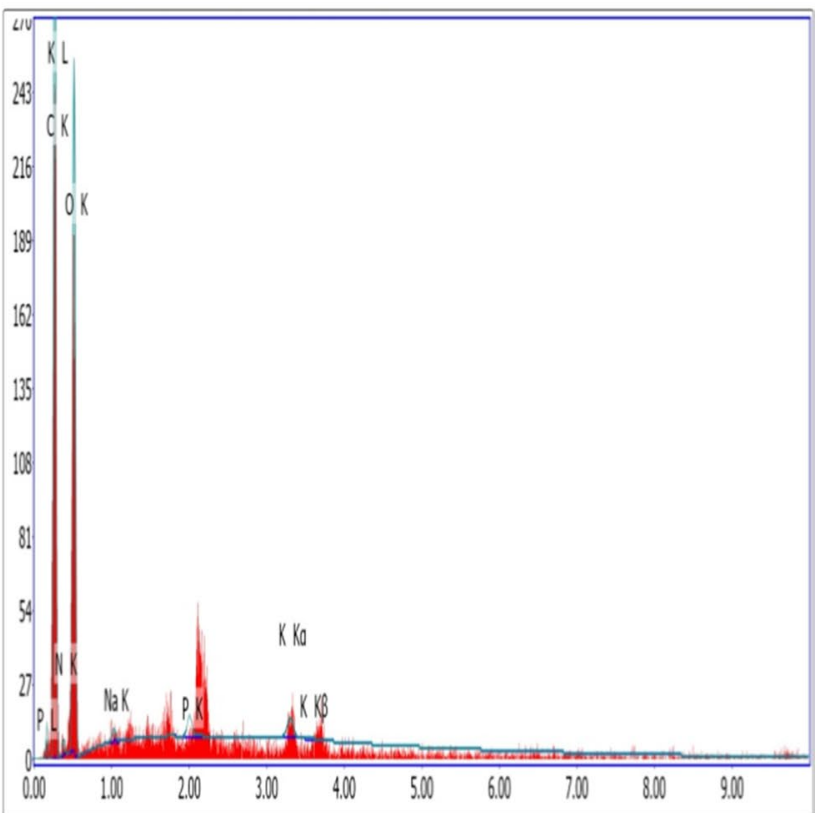

(b)

Fig. 7 a EDX analysis of Eichhornia crassipes roots unloaded with phenol and cyanide and b loaded with phenol and cyanide

and $1.4 \%$ of potassium, $0.75 \%$ and $0.77 \%$ phosphorus and $3.74 \%$ and $3.99 \%$ of nitrogen in unloaded phenol and cyanide and loaded phenol and cyanide of the plant shoots, respectively.
It is observed from the EDX analysis results that the weight $\%$ of phenol and cyanide was found as increase the amount weight $\%$ of $\mathrm{C}, \mathrm{O}, \mathrm{N}$ and $\mathrm{Na}$ after phytoremediation (Singh and Balomajumder 2016). 


\section{Influence of process parameters on phenol and cyanide removal by Eichhornia crassipes}

\section{Influence of $\mathrm{pH}$}

The results of influence of $\mathrm{pH}$ on removal of phenol and cyanide by Eichhornia crassipes are presented in Fig. 8a and $\mathrm{b}$, respectively. To evaluate the effect of $\mathrm{pH}$ on phenol and cyanide removal, the plants were grown at $\mathrm{pH}$ range (2-12), under the identical conditions. It is observed from figure that percentage removal of phenol and cyanide increases very gradually in acidic region (up to $\mathrm{pH} 8$ ) and decreases sharply thereafter.

Phenol remains constant in acidic $\mathrm{pH}$ range where the phenol remains in undissociated forms. Though at $\mathrm{pH}$ more than its pKa (9.96), a reduction in removal percentage is observed representing phenol removal mostly in its undissociated form. Since cyanide has a pKa of 9.39 maximum removal of cyanide is found at $\mathrm{pH} 8-10$. In $\mathrm{pH}$ range (4-8), there is a reduction in percentage removal of cyanide which could be recognised to hydrolysis of weak acid dissociable cyanides to hydrogen cyanide. As a result, hydrogen cyanide is very hydrophilic its affinity to be removed at low $\mathrm{pH}$ is noticeably reduced. Though at higher $\mathrm{pH}$, the cyanide occurs in undissociated form.

It may be owing to reasons that the maximum removal of phenol found in $\mathrm{pH}$ range 7-8 and cyanide removal occurs in pH range 8-11 (Busca et al. 2008; Dash et al. 2009). The uptake increases with the $\mathrm{pH}$ increases due to the deprotonation of the active sites (Smolyakov et al. 2010). Pollutant removal through bioaccumulation is strongly depends on $\mathrm{pH}$ and found maximum at $\mathrm{pH}$ above 8 for aquatic plants. Lower removal of phenol and cyanide at higher $\mathrm{pH}$ is due to the occurrence of excess $\mathrm{OH}^{-}$ions competing with pollutants for the adsorption sites. At $\mathrm{pH} 8$, noteworthy removal of the phenol and cyanide still followed (Fig. 8a and b).

It is well-known that the $\mathrm{pH}$ controls the plant growth through affecting availability and movement of ions (Jacobson et al. 1962). The adsorption of either hydrogen ions or hydroxyl ions takes place quite strongly. At higher $\mathrm{pH}$, hydroxyls are favoured, whereas hydrogen ions are adsorbed favourably at lower $\mathrm{pH}$. Therefore, hydration of plants surface gives the properties of an ion-exchanger to the plants surface; freely adsorbing cations or anions from the solution. It is also cleared from FTIR study that the surface of plant contains a number of functional groups like carboxyl, sulphate, phenolic, carbonyls, phosphate, etc., which are responsible for growing negative charges on its surface.

\section{Influence of initial concentration}

The influence of initial concentration on removal of phenol and cyanide by Eichhornia crassipes is shown in Fig. 9a and $b$, respectively and in Table 3.1. To study the influence of initial concentration with contact time, initial concentration was varied from $100-1000 \mathrm{mg} / \mathrm{L}$ for phenol and $10-100 \mathrm{mg} / \mathrm{L}$ for cyanide.

From the Figure, it is clear that uptake of phenol and cyanide was observed to decrease with the increasing time of exposure of the plant and then becomes constant. It could be observed from Figures that the reaction may be slower due to the reduction of the pollutant concentration.
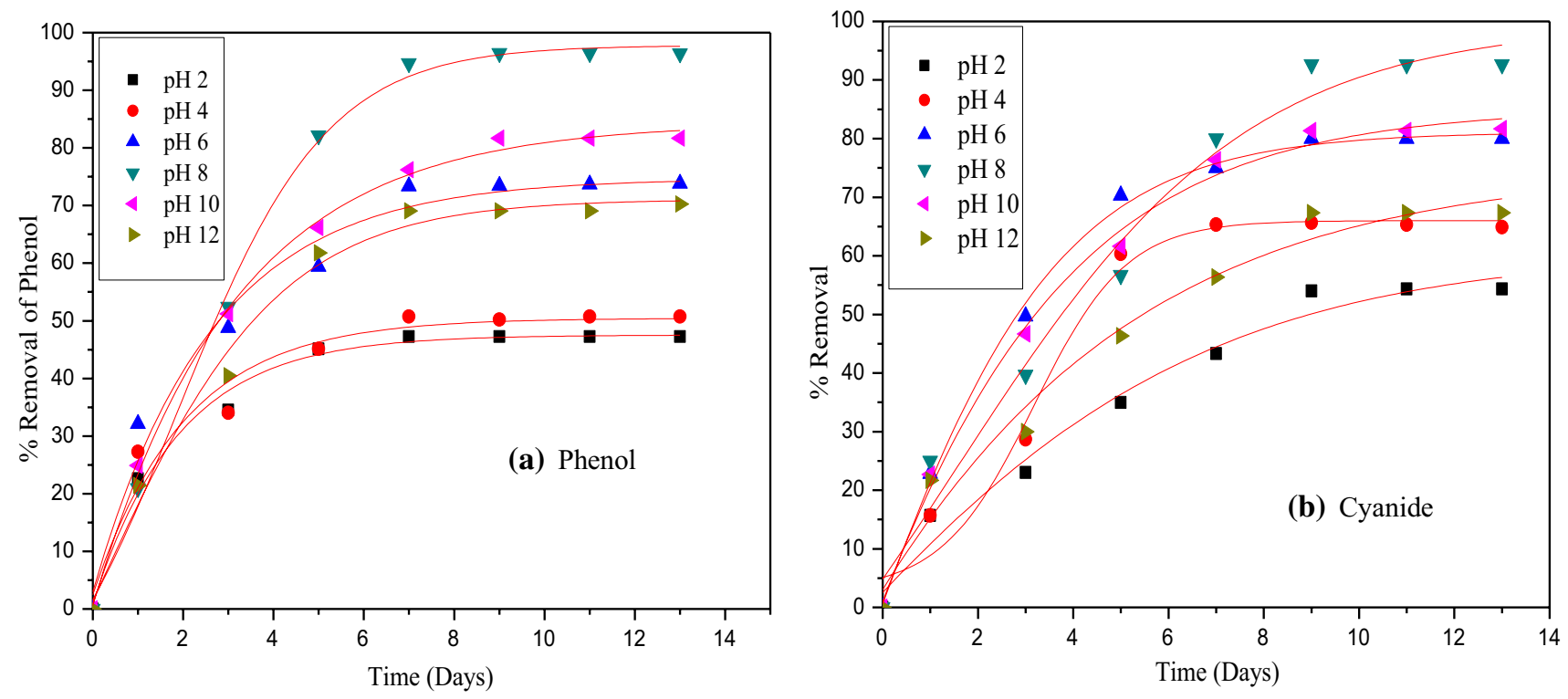

Fig. 8 Effect of $\mathrm{pH}$ on removal of phenol and cyanide from binary component synthetic/simulated wastewater by Eichhornia crassipes a phenol b cyanide 


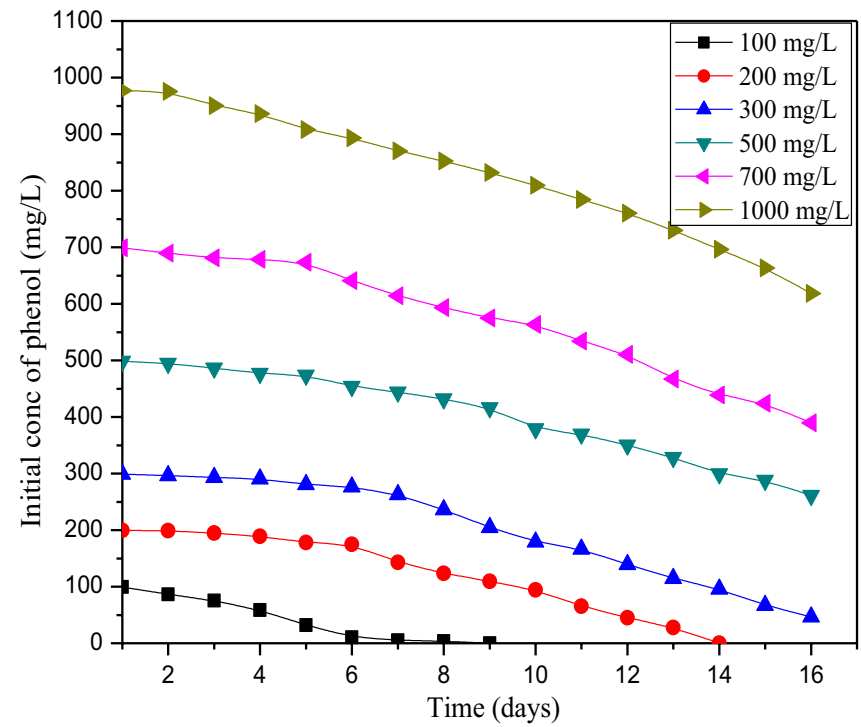

(a)

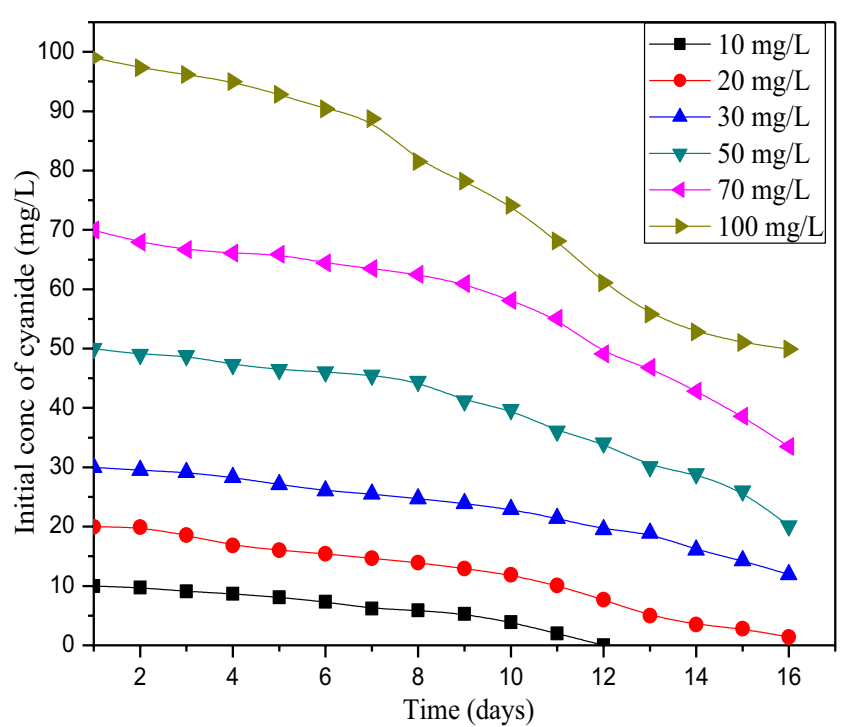

(b)

Fig. 9 Effect of initial concentration on removal of phenol and cyanide from binary component synthetic/simulated wastewater by Eichhornia crassipes a phenol b cynaide. (Reference operating conditions: Initial $\mathrm{pH} 8$, Temperature $30{ }^{\circ} \mathrm{C}$ )

At initial stage, there was a high concentration gradient available between bulk solution and plants and as time proceed equilibrium was maintained between bulk solution and plants. The phytoremediation capability of the plant was stated by the observation of pollutant concentrations before and after uptake. The increasing tendency of percentage removal with the increasing cultivation period. However, uptake capacity was found to be decreased with the increase in time. It was observed that phenol and cyanide concentration decreased with time from day 1 to day 13.

The reduction in percentage removal of phenol and cyanide with the increase in the initial concentration depends on the uptake capacity of the particular plant site, transport mechanism and tolerance limit of the plant (Scragg
2006). The decrease in initial growth, could be owing to the decrease of a fraction of the cells, produced by the pollutant toxic effect (Scragg 2006). Accumulation of phenol and cyanide onto the surface of plants is due to biosorption monitored by vigorous uptake into cells of the plant (Dhir, 2009). The accumulation capacity of pollutants depends on the basis of variation of affinity and competition between ions during uptake (Dhir et al. 2009). The reduction in percentage removal of phenol and cyanide with the increase in the initial concentration depends on the uptake capacity of the particular plant site, transport mechanism and tolerance limit of the plant (Reynel-Avila et al. 2011; Scragg 2006).

Table 1 indicates the growth analysis of plant at different age of plant and treatment with various phenol and cyanide

Table 1 Measurement of shoot and root length of the Eichhornia crassipes at different growth period under the treatment of various phenol and cyanide concentrations

\begin{tabular}{|c|c|c|c|c|c|c|c|c|}
\hline \multicolumn{9}{|c|}{ Eichhornia crassipes } \\
\hline Age (days) & Length and weight & Control & $\begin{array}{l}\text { Phenol:100 } \\
\text { Cyanide:10 }\end{array}$ & $\begin{array}{l}\text { Phenol:200 } \\
\text { Cyanide:20 }\end{array}$ & $\begin{array}{l}\text { Phenol:300 } \\
\text { Cyanide:30 }\end{array}$ & $\begin{array}{l}\text { Phenol:500 } \\
\text { Cyanide:50 }\end{array}$ & $\begin{array}{l}\text { Phenol:700 } \\
\text { Cyanide:70 }\end{array}$ & $\begin{array}{l}\text { Phenol: } 1000 \\
\text { Cyanide: } 100\end{array}$ \\
\hline \multirow[t]{3}{*}{4} & Roots length (cm) & 10.10 & 9.81 & 9.00 & 8.70 & 7.72 & 6.86 & 5.90 \\
\hline & Shoots length $(\mathrm{cm})$ & 12.41 & 11.90 & 10.30 & 9.60 & 8.95 & 7.59 & 6.79 \\
\hline & Dry weight of plant (gm) & 9.88 & 9.74 & 9.00 & 8.12 & 7.68 & 6.55 & 5.01 \\
\hline \multirow[t]{3}{*}{8} & Roots length (cm) & 14.66 & 14.00 & 13.60 & 12.05 & 11.06 & 9.95 & 8.90 \\
\hline & Shoots length (cm) & 16.57 & 15.20 & 14.05 & 13.68 & 12.07 & 10.70 & 9.90 \\
\hline & Dry weight of plant (gm) & 8.00 & 7.98 & 7.00 & 6.89 & 6.00 & 5.01 & 4.88 \\
\hline \multirow[t]{3}{*}{13} & Roots length (cm) & 16.60 & 16.22 & 15.99 & 14.83 & 13.10 & 11.90 & 10.21 \\
\hline & Shoots length (cm) & 17.99 & 17.2 & 16.60 & 16.00 & 15.09 & 14.8 & 12.20 \\
\hline & Dry weight of plant (gm) & 6.98 & 6.77 & 5.00 & 4.89 & 4.36 & 4.30 & 3.98 \\
\hline
\end{tabular}


concentrations ranging between $100-1000 \mathrm{mg} / \mathrm{L}$ of phenol and $10-100 \mathrm{mg} / \mathrm{L}$ of cyanide. It was seen that the length of shoot and root of Eichhornia crassipes plants increased gradually at the initial stage of low concentration of phenol and cyanide. This might be due to the uptake of phenol and cyanide species as a nutrient material for the growth of plant. However, increase in phenol and cyanide concentration causes significant decrease in shoot and root length of plants. From 13 day old Eichhornia crassipes plants presented in Table 3.1, drastic reductions in shoot and root length of the plant were observed at $1000 \mathrm{mg} / \mathrm{L}$ of phenol and $100 \mathrm{mg} / \mathrm{L}$ of cyanide concentration as compared to the control plants viz. 17.99 to $12.20 \mathrm{~cm}$ of shoot length, 16.60 to $10.21 \mathrm{~cm}$ of root length and 6.98 to $3.90 \mathrm{gm}$ of dry weight of plant.

The results revealed that the growth rate of plants is highly affected by initial concentration of phenol and cyanide.

\section{Influence of phenol and cyanide on biochemical changes of Eichhornia crassipes}

The effect of phenol and cyanide on biochemical parameters of Eichhornia crassipes, is shown in Table 2. To study the influence of phenol and cyanide on biochemical parameters of plants, initial concentration was varied from $100-1000 \mathrm{mg} / \mathrm{L}$ for phenol and $10-100 \mathrm{mg} / \mathrm{L}$ for cyanide.

The toxic effect on the plant was detected due to reduction in chlorophyll, sugar, and protein content of the test plants for binary solution of synthetic/simulated wastewater.
Chlorophyll contents are significant indicators of loss of the photosynthetic system of the plants encouraged by the environment (Maxwell and Johnson 2000).

The strong reducing ability of phenol and cyanide may cause phytotoxicity to the plants. The reduction in parameters chlorophyll, sugar, and protein contents of the Eichhornia crassipes indicated a comparable tendency of deterioration equivalent to the increase in the concentration of phenol and cyanide. The reduction in parameters was detected with the increasing exposure time (Cheng et al. 2007). It could be owing to deterioration in sugar content at the higher concentration; therefore, the energy of the plant was reduced. Similar clarifications on reduction in chlorophyll, protein and sugar contents in several aquatic plants for phenol and cyanide uptake were described by Xiao-Zhang and Ji-Dong (Xiao-Zhang 2008). After 5 days, the new young branch was grown for both mono and binary solution of phenol and cyanide. This might be owing to the fact that at initial stage, plants were in stressed situation; after 5 days of operation, the plants were accommodated in to the toxic environments. The formation of (reactive oxygen species) ROS such as superoxide and $\mathrm{H}_{2} \mathrm{O}_{2}$ throughout the stressed condition was due to the biochemical mechanism of the plant.

\section{Relative growth rate (RGR), bioconcentration factor (BCF) and translocation factor (TF)}

To study the effect of RGR, BCF and TF on the removal of phenol and cyanide using Eichhornia crassipes, initial
Table 2 Chlorophyll, sugar and protein variations in Eichhornia crassipes after 13 days exposure to phenol and cyanide in binary component solution

\begin{tabular}{|c|c|c|c|c|c|}
\hline Plant part & $\begin{array}{l}\text { Phenol concen- } \\
\text { tration }(\mathrm{mg} / \mathrm{L})\end{array}$ & $\begin{array}{l}\text { Cyanide } \\
\text { concentration } \\
(\mathrm{mg} / \mathrm{L})\end{array}$ & $\begin{array}{l}\text { Chlorophyll content } \\
\text { (mg/g dry weight) }\end{array}$ & $\begin{array}{l}\text { Sugar content } \\
\text { (mg/g dry } \\
\text { weight) }\end{array}$ & $\begin{array}{l}\text { Protein content } \\
\mathrm{mg} / \mathrm{g} \text { dry } \\
\text { weight) }\end{array}$ \\
\hline \multirow[t]{6}{*}{ Roots } & 100 & 10 & - & $50.90 \pm 0.98$ & $57 \pm 0.99$ \\
\hline & 200 & 20 & - & $48 \pm 0.88$ & $55.78 \pm 0.75$ \\
\hline & 300 & 30 & - & $42.65 \pm 0.44$ & $50.91 \pm 0.36$ \\
\hline & 500 & 50 & - & $32.87 \pm 0.38$ & $31.87 \pm 0.44$ \\
\hline & 700 & 70 & - & $29.87 \pm 0.72$ & $24.81 \pm 0.85$ \\
\hline & 1000 & 100 & - & $27 \pm 0.28$ & $20.93 \pm 0.54$ \\
\hline \multirow[t]{6}{*}{ Stem } & 100 & 10 & - & $32.43 \pm 0.76$ & $79.87 \pm 0.55$ \\
\hline & 200 & 20 & - & $30.98 \pm 0.32$ & $75.67 \pm 0.05$ \\
\hline & 300 & 30 & - & $25.54 \pm 0.54$ & $71.87 \pm 0.77$ \\
\hline & 500 & 50 & - & $23.44 \pm 0.19$ & $67.87 \pm 0.88$ \\
\hline & 700 & 70 & - & $21.44 \pm 0.62$ & $50 \pm 0.76$ \\
\hline & 1000 & 100 & - & $19.87 \pm 0.54$ & $45.87 \pm 0.54$ \\
\hline \multirow[t]{6}{*}{ Leaves } & 100 & 10 & $18.73 \pm 0.43$ & $50.54 \pm 0.21$ & $128 \pm 0.90$ \\
\hline & 200 & 20 & $15.87 \pm 0.11$ & $49.00 \pm 0.73$ & $121 \pm 0.22$ \\
\hline & 300 & 30 & $12.65 \pm 0.45$ & $41.97 \pm 0.54$ & $104.12 \pm 0.57$ \\
\hline & 500 & 50 & $13.99 \pm 0.76$ & $39.88 \pm 0.62$ & $92.08 \pm 0.81$ \\
\hline & 700 & 70 & $11.43 \pm 0.97$ & $33.96 \pm 0.43$ & $89.65 \pm 0.22$ \\
\hline & 1000 & 100 & $9.87 \pm 0.77$ & $29.83 \pm 0.18$ & $85 \pm 0.43$ \\
\hline
\end{tabular}


concentration was varied from $100-1000 \mathrm{mg} / \mathrm{L}$ of phenol and $10-100 \mathrm{mg} / \mathrm{L}$ of cyanide. The effect of RGR, BCF and TF is shown in Tables 3 and 4.

The relative growth rate of the plant at different concentrations of phenol and cyanide was calculated by weighing the initial weight of fresh Eichhornia crassipes before uptake of phenol and cyanide and final weight of the plant after uptake of pollutant after 13 days. The relative growth rate (RGR) of Eichhornia crassipes plant materials was calculated at different initial concentrations of cyanide and phenol by using Eq. (2) (Maine et al. 2001).

The bioconcentration factor was calculated by dividing the concentration of the toxic pollutant phenol and cyanide in the plant to the concentration in synthetic/simulated nutrient solution given in Eq. (3). The concentration of toxic pollutant phenol and cyanide in the parts of the plant was estimated by acid digestion with $\mathrm{HNO}_{3}-\mathrm{HClO}_{4}$ in 2:1 ratio (v/v) (Singh et al. 2008).

The growth of plant was increased with the decrease in initial concentration of phenol and cyanide with time. The plant growth was inhibited at the higher concentration of phenol and cyanide owing to decrease in dissolve oxygen (D.O) and the osmotic influence on the cell of the plant (Chandra and Yadav 2010). The measurement of RGR can be used to determine the plant health throughout the experimental period, and $\mathrm{BCF}$ was calculated to determine the capability of plant for the accumulation of phenol and cyanide.

The RGR value of the Eichhornia crassipes was observed as $0.069,0.069,0.061,0.052,0.039$ and $0.021 \mathrm{mg} / \mathrm{day}$ at
100, 200, 300, 500, 700 and $1000 \mathrm{mg} / \mathrm{L}$, respectively, for phenol in mono component solution. Hence, no toxic effect of phenol on the Eichhornia crassipes was found for the concentration ranging from 100 to $200 \mathrm{mg} / \mathrm{L}$, then constant RGR value as $0.069 \mathrm{mg} /$ day. RGR value for cyanide in mono component solution was found to be decreased from 0.030 to $0.010 \mathrm{mg} / \mathrm{day}$ at increase initial concentration from 10 to $100 \mathrm{mg} / \mathrm{L}$. Similarly, when the pollutant concentration in water increases, the amount of pollutants accumulation in plants increases; therefore, the RGR value decreases. The RGR value for binary component solution of phenol and cyanide ratio (10:1) was observed to be $0.066,0.064,0.061$, $0.050,0.031$, and $0.018 \mathrm{mg} /$ day with the increase in initial concentration (Table 3). Therefore, it was found that RGR value is more for the mono component solution of phenol and cyanide than the binary component solution. This is due to the fact that both components show antagonistic effect on each other; as a result, the growth of plant reduced in binary solution. Therefore, RGR value is reduced for binary component solution.

In monocomponent solution, the BCF value for phenol was found to be 900,610 and 543 in stem, leaves and roots, respectively, while $\mathrm{BCF}$ value for cyanide was found to be 800,623 and 500 in stem, leaves and roots, respectively (Table 4). Therefore, the BCF value of phenol and cyanide in stem of Eichhornia crassipes was more than other parts of the plant. This demonstrates that phenol was more accumulated in the stems of Eichhornia crassipes than cyanide. BCF was calculated to determine the ability of Eichhornia crassipes for the accumulation of phenol. BCF for phenol in
Table 3 RGR in plants after 13 days exposure to phenol and cyanide in mono and binary component solution

\begin{tabular}{|c|c|c|c|c|c|c|}
\hline \multicolumn{7}{|c|}{ Eichhornia crassipes } \\
\hline \multicolumn{4}{|c|}{ Mono-component solution } & \multicolumn{3}{|c|}{ Binary-component solution } \\
\hline Phenol (mg/L) & RGR & Cyanide(mg/L) & RGR & Phenol (mg/L) & Cyanide $(\mathrm{mg} / \mathrm{L})$ & RGR \\
\hline 100 & 0.069 & 10 & 0.030 & 100 & 10 & 0.066 \\
\hline 200 & 0.069 & 20 & 0.028 & 200 & 20 & 0.064 \\
\hline 300 & 0.061 & 30 & 0.025 & 300 & 30 & 0.061 \\
\hline 500 & 0.052 & 50 & 0.020 & 500 & 50 & 0.050 \\
\hline 700 & 0.039 & 70 & 0.016 & 700 & 70 & 0.031 \\
\hline 1000 & 0.020 & 100 & 0.010 & 1000 & 100 & 0.018 \\
\hline
\end{tabular}

Eichhornia crassipes

Table 4 BCF and TF in plants after 13 days exposure to phenol and cyanide in mono and binary component solution

\begin{tabular}{|c|c|c|c|c|c|c|c|c|}
\hline \multicolumn{6}{|c|}{ Mono-component solution } & \multicolumn{3}{|c|}{ Binary-component solution } \\
\hline Phenol(mg/L) & $\mathrm{BCF}$ & $\mathrm{TF}$ & Cyanide(mg/L) & $\mathrm{BCF}$ & $\mathrm{TF}$ & $\begin{array}{l}\text { Phenol and cya- } \\
\text { nide }(\mathrm{mg} / \mathrm{L})\end{array}$ & $\mathrm{BCF}$ & $\mathrm{TF}$ \\
\hline Stem & 900 & 1.01 & Stem & 800 & 1.00 & Stem & 1123 & 0.98 \\
\hline Leaves & 610 & 1.01 & Leaves & 623 & 0.90 & Leaves & 810 & 0.87 \\
\hline Roots & 543 & 0.89 & Roots & 500 & 0.90 & Roots & 600 & 0.79 \\
\hline
\end{tabular}


mono component solution was 543 , but for multicomponent solution, BCF was found to be 600 which shows high ability of Eichhornia crassipes for the accumulation of phenol. This shows that phenol was more accumulated in the root of the plant in the presence of cyanide. Though, since the stem biomass was higher than root biomass, phenol and cyanide in the stem part had the maximum proportions of the pollutant in the entire plant. In addition, the value of BCF for phenol and cyanide in multicomponent solution was found more than mono component solution. The translocation factor is used to define the translocation of pollutants from roots to stem and stem to leaf (Ma et al. 2001). The value of TF greater than 1 shows that the plants have able to translocation of pollutants (Ma et al. 2001). The value of TF of phenol and cyanide ranged from 1.01 to 0.89 and 1.00 to 0.90 , respectively, in the stem to roots of Eichhornia crassipes in mono component solution. The data show that the phenol translocation is more than cyanide in roots to stem of the plant. According to Baker and walker 1990, the TF varies species to species and metal to metal (Baker and Walker 1990). The value of TF more than 1 defines that the plant has capability to transfer pollutant from root to stem (Ma et al. 2001). The TF value more than 1 indicated that Eichhornia crassipes effectively transfer pollutants from root to stem. The TF of phenol and cyanide in binary solution is 0.98 to 0.79 , indicate $\mathrm{TF}$ is reduced in binary component solution. Low value of TF of pollutants to parts of plant could be due to adoption of pollutants inside root cell to reduce it non-toxic.

\section{Uptake kinetics parameters for phenol and cyanide}

The uptake kinetics of phenol and cyanide were carried out for two growth stages of plants. Outlet solution containing phenol and cyanide was collected, and the rate of phenol and cyanide uptake was predicted from the difference in concentration at the inlet and outlet. The rate of phenol and cyanide uptake by plants was calculated by linear regression analysis of 4 consecutive sampling times of phenol and cyanide solutions measured from the pots during depletion. At each stage, the weight of the absorbing roots of the plant was also determined (Nye and Tinker 1977). It was assumed the uptake experiment that uptake of water by the plant roots, which further transports to the body of plant and due to transpiration some water may get lost, did not affect the phenol and cyanide concentrations in the liquid medium.

The phenol and cyanide ions uptake kinetic parameters $\left(V_{\max }\right.$ and $K_{\mathrm{m}}$ ) of plants are given in Table. 3.4. The $V_{\max }$ and $K_{\mathrm{m}}$ were calculated with the help of fitted coefficients obtained by fitting the solution phenol and cyanide concentration and uptake rate data on the Michaelis-Menten equation (Roshani and Narayanasamy 2010).

For water hyacinth plant, at root length elongation stage, the values of $V_{\max }$ were obtained as $12.52 \mu \mathrm{g} / \mathrm{g}$ root per $\mathrm{h}$ for phenol and $14.99 \mu \mathrm{g} / \mathrm{g}$ root per $\mathrm{h}$ for cyanide, which decreased to $5.84 \mu \mathrm{g} / \mathrm{g}$ root per $\mathrm{h}$ and $5.68 \mu \mathrm{g} / \mathrm{g}$ root per $\mathrm{h}$ for phenol and cyanide, respectively, at total height change stage. Also, $K_{\mathrm{m}}$ values at $5.20 \mathrm{mM}$ and $0.39 \mathrm{mM}$ for phenol and cyanide at root length elongation stage increased to $5.83 \mathrm{mM}$ for phenol and decreased to $0.25 \mathrm{mM}$ for cyanide at total height change stage (Table 5). Also, during 4 to 13 days of water hyacinth during the root length elongation stage, the maximum phenol and cyanide uptake per unit weight of the roots were 0.085 and $0.088 \mu \mathrm{g} / \mathrm{g}$ root per $\mathrm{h}$ for phenol and cyanide with $9.608 \mathrm{mM}$ of phenol and $0.514 \mathrm{mM}$ of cyanide concentration.

Table 5 Values of Vmax and $K m$ for phenol and cyanide uptake equation at different growth stages of Eichhornia crassipes

\begin{tabular}{|c|c|c|c|c|c|c|c|c|}
\hline \multicolumn{9}{|l|}{ Water hyacinth } \\
\hline & \multicolumn{6}{|c|}{ Initial concentration of phenol (mM) } & \multirow{2}{*}{ 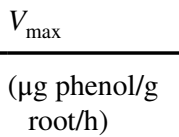 } & \multirow{2}{*}{$\frac{K_{\mathrm{m}}}{(\mathrm{mM})}$} \\
\hline Growth stage of water hyacinth & 1.053 & 2.111 & 3.180 & 5.301 & 7.400 & 9.608 & & \\
\hline & \multicolumn{8}{|c|}{ Uptake rate $(\mu \mathrm{g} / \mathrm{g}$ root $/ \mathrm{h})$} \\
\hline Root length elongation & 0.021 & 0.034 & 0.053 & 0.063 & 0.071 & 0.085 & 12.52 & 5.20 \\
\hline \multirow[t]{2}{*}{ Total height change } & 0.010 & 0.015 & 0.021 & 0.026 & 0.032 & 0.039 & 5.84 & 5.83 \\
\hline & \multicolumn{6}{|c|}{ Initial concentration of cyanide (mM) } & $V_{\max }$ & $K_{\mathrm{m}}$ \\
\hline \multirow[t]{2}{*}{ Growth stage of water hyacinth } & 0.051 & 0.103 & 0.154 & 0.257 & 0.360 & 0.514 & $\begin{array}{l}(\mu \mathrm{g} \text { cyanide } / \mathrm{g} \\
\operatorname{root} / \mathrm{h})\end{array}$ & $(\mathrm{mM})$ \\
\hline & \multicolumn{8}{|c|}{ Uptake rate $(\mu \mathrm{g} / \mathrm{g}$ root/h$)$} \\
\hline Root length elongation & 0.019 & 0.031 & 0.043 & 0.056 & 0.072 & 0.088 & 14.99 & 0.39 \\
\hline Total height change & 0.01 & 0.016 & 0.022 & 0.029 & 0.032 & 0.039 & 5.68 & 0.25 \\
\hline
\end{tabular}




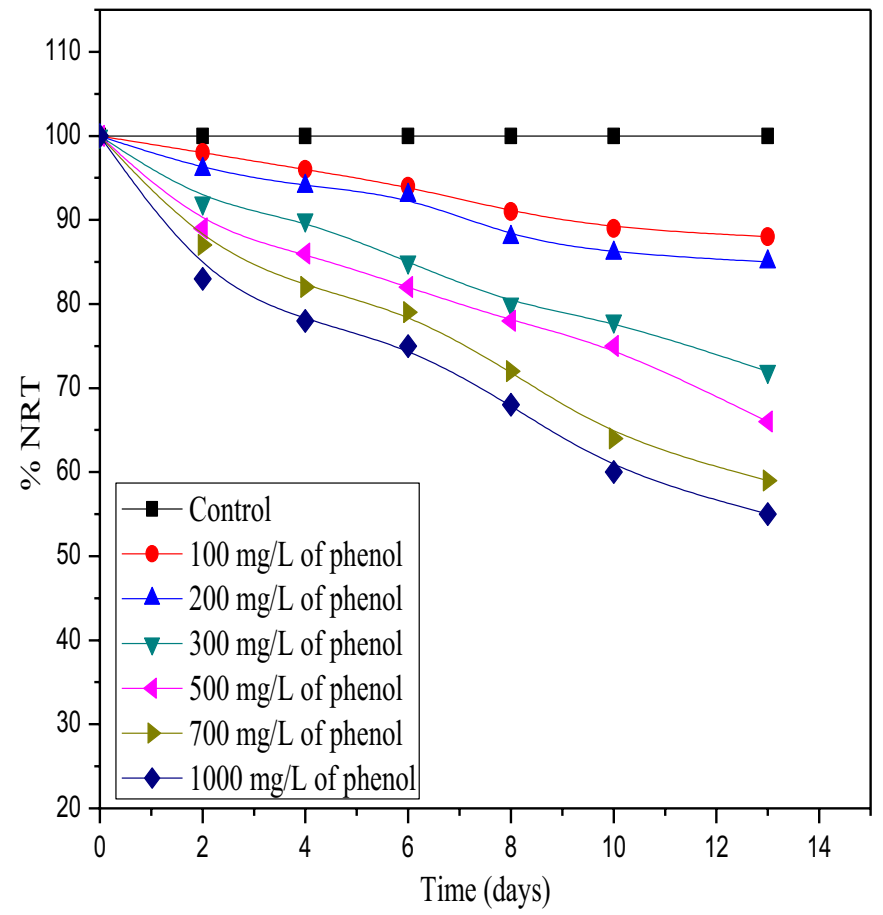

(a)

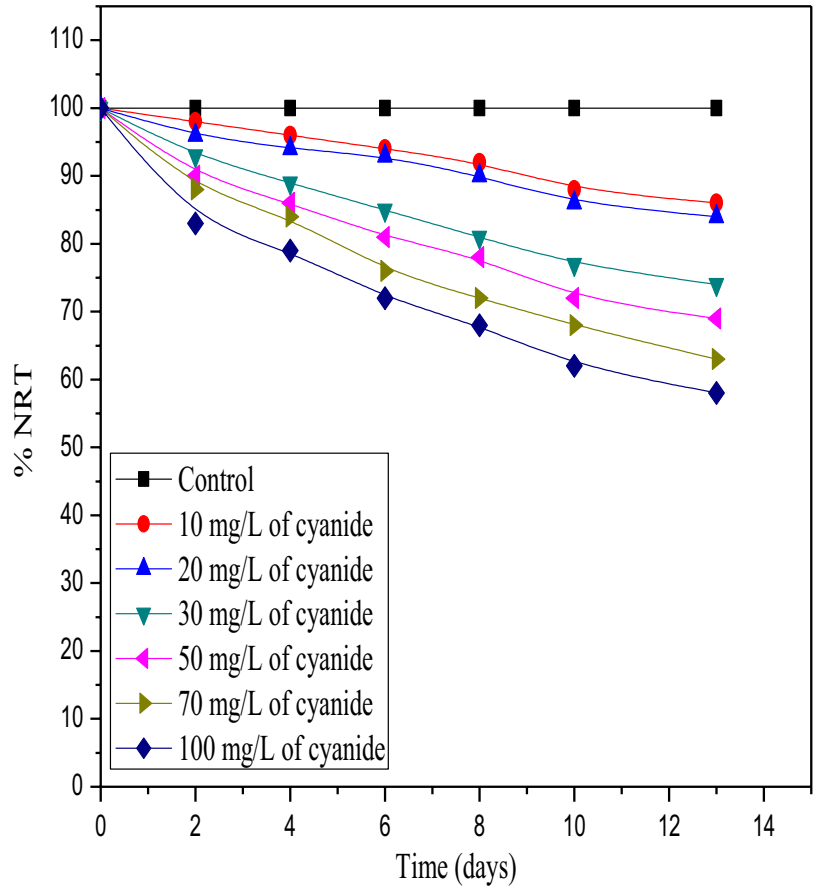

(b)

Fig. 10 Relative transpiration of Eichhornia crassipes at different concentrations. a Phenol b Cyanide

\section{Normalized relative transpiration (NRT)}

Figure 10a and $\mathrm{b}$ shows the variation in $\%$ NRT with time for Eichhornia crassipes plant, respectively. Normalized relative transpiration is expressed as the degree of the toxicity of pollutants in the plants. Transpiration can be calculated directly by measuring the weight of the plant with pot (Trapp et al. 2000). The transpiration is normalized with respect to initial transpiration. To consider the fact that healthy trees grow quickly and therefore increase transpiration, the normalized relative transpiration (NRT) is calculated by using Eq. 6 .

Water hyacinth with $1000 \mathrm{mg} / \mathrm{L}$ of phenol shows \% NRT, i.e. $55.09 \%$, and plants with $100 \mathrm{mg} / \mathrm{L}$ of cyanide show $\%$ NRT, i.e. $58.91 \%$. This variation is due to toxicity of phenol and cyanide for plant. In the phenol and cyanide toxicity experiments, phenol and cyanide decreased the relative transpiration of water hyacinth; higher concentrations led to lower transpiration. At the lowest concentration $(200 \mathrm{mg} / \mathrm{L}$ of phenol and $20 \mathrm{mg} / \mathrm{L}$ of cyanide), transpiration was only slightly reduced and the plants survived without any morphological changes. The transpiration rate is a very sensitive toxicity parameter because stress factors, e.g. toxic substances, have a high impact on the water balance of plants. Therefore, chemical stress makes a quick decrease in transpiration and a drying of leaves.

\section{Conclusions}

The current study highlighted that Eichhornia crassipes used as a good accumulator of phenol and cyanide. The plant was successfully removed up to $96.42 \%$ of phenol $(300 \mathrm{mg} / \mathrm{L})$ and $92.66 \%$ of cyanide $(30 \mathrm{mg} / \mathrm{L})$. During 13 days contact with phenol and cyanide, biochemical parameters such as protein, sugar and chlorophyll contents have shown a decreasing trend due to accumulation of phenol and cyanide. The influence of physicochemical parameters with time such as $\mathrm{pH}$ and initial concentration of phenol and cyanide were also evaluated. Phenol accumulation was found toxic above concentration $200 \mathrm{mg} / \mathrm{L}$ indicate toxicity symptoms, i.e. delay in growth and yellowing of the leaves at $\mathrm{pH} 8$. However, cyanide was indicated toxic symptoms above $20 \mathrm{mg} / \mathrm{L}$ concentrations. BCF and RGR value was found more for the mono component solution of phenol and cyanide than the binary component solution. BCF shows that phenol was more accumulated in the root of the plant in the presence of cyanide. The value of TF more than 1 indicated that Eichhornia crassipes effectively transfer pollutants from root to stem.

Acknowledgements The author appreciatively acknowledges financial support provided by the MHRD assistantship by Government of India and Indian Instrumentation Center IIT Roorkee, Chemical Engineering Department, IIT Roorkee, for the facility provided for conducting research work. 
Financial Disclosure Statement The author(s) received no specific funding for this work.

\section{Declarations}

Ethical standards This article does not contain any studies with human participants or animals performed by any of the authors.

Informed consent For this type of study formal consent is not required.

Open Access This article is licensed under a Creative Commons Attribution 4.0 International License, which permits use, sharing, adaptation, distribution and reproduction in any medium or format, as long as you give appropriate credit to the original author(s) and the source, provide a link to the Creative Commons licence, and indicate if changes were made. The images or other third party material in this article are included in the article's Creative Commons licence, unless indicated otherwise in a credit line to the material. If material is not included in the article's Creative Commons licence and your intended use is not permitted by statutory regulation or exceeds the permitted use, you will need to obtain permission directly from the copyright holder. To view a copy of this licence, visit http://creativecommons.org/licenses/by/4.0/.

\section{References}

Abbas Z, Arooj F, Ali S, Zaheer IE, Rizwan M, Riaz MA (2019) Phytoremediation of landfill leachate waste contaminants through floating bed technique using water hyacinth and water lettuce. Int J Phytorem 21:1356-1367

Akcil A (2003) Destruction of cyanide in gold mill effluents: Biological versus chemical treatments. Biotechnol Adv 21:501-511

Ali H, Khan E, Sajad MA (2013) Phytoremediation of heavy metalsConcepts and applications. Chemosphere 91:869-881

APHA (2001) Standard Methods for the Examination of Water and Wastewater, 20th edn. American Public Health Association, Washington, DC

Arslan M, Imran A, Khan QM, Afzal M (2017) Plant-bacteria partnerships for the remediation of persistent organic pollutants. Environ Sci Pollut Res 24:4322-4336

Baker AJM, Walker PL (1990) Ecophysiology of metal uptake by tolerant plants. In: Shaw AJ (ed) Heavy Metal Tolerance in Plants: Evolutionary Aspects. CRC Press, Boca Raton FL, p 155

Burges A, Alkorta I, Epelde L, Garbisu C (2018) From phytoremediation of soil contaminants to phytomanagement of ecosystem services in metal contaminated sites. Int J Phytorem 20:384-397

Busca G, Berardinelli S, Resini C, Arrighi L (2008) Technologies for the removal of phenol from fluid streams: A short review of recent developments. J Hazard Mater 160:265-288

Chandra R, Yadav S (2010) Potential of Typha angustifolia for phytoremediation of heavy metals from aqueous solution of phenol and melanoidin. Ecol Eng 36:1277-1284

Cheng H, Xu W, Liu L, Zhao Q, Chen G (2007) Application of composted sewage sludge (CSS) as s soil amendment for turf grass growth. Ecol Eng 29:96-104

Cunningham SD, Ow DW (1996) Promises and prospects of phytoremediation. Plant Physiol 110:715-719

Dash RR, Gaur A, Balomajumder C (2009) Cyanide in industrial wastewaters and its removal: A review on biotreatment. J Hazard Mater 163:1-11

Dash RR, Dash RR, Balomajumdar C (2014) Treatment of cyanide bearing effluents by adsorption, biodegradation and combined processes: effect of process parameters. Desalin Water Treat 52:3355-3366

Daud MK, Ali S, Abbas Z, Zaheer IE, Ahsan Riaz M, Malik A, Hussain A, Rizwan M, Zia-ur-Reh M (2018) Potential of duckweed (Lemna minor) for the phytoremediation of landfill leachate. J Chem 1-9

Dhir B, Sharmila P, Saradhi PP (2009) Potential of aquatic macrophytes for removing contaminants from the environment. Crit Rev Environ Sci Technol 39:1-28

Dubois M, Gilles KA, Hamilton JK, Rebers PA, Smith F (1956) Colorimetric method for determination of sugars and related substances. Analytival Chemistry 28:350-356

Ebel M, Michael WH, Evangelou AS (2007) Cyanide phytoremediation by water hyacinths (Eichhornia crassipes). Chemosphere 66:816-823

Hejna M, Moscatelli A, Stroppa N, Onelli E, Pilu S, Baldi A, Rossi L (2020) Bioaccumulation of heavy metals organic pollutants. Environ Sci Pollut Resour 24:4322-4336

Hoagland DR, Arnon DI (1950) The water-culture method for growing plants without soil. Circular Calif Agric Exp Station 347:32

Jacobson L, Overstreet R, King HM, Handley R (1962) The effect of $\mathrm{pH}$ and temperature on the absorption of potassium and bromide by barley roots. Plant Physiol 37:821-825

Leguizamo MAO, Gómez WDF, Sarmiento MCG (2017) Native herbaceous plant species with potential use in phytoremediation of heavy metals, spotlight on wetlands - A review. Chemosphere 168:1230-1247

Lowry OH, Rosebraugh NJ, Farr AL, Randall RJ (1951) Protein measurement with folin-phenol reagent. J Biol Chem 193:265-275

Ma LQ, Komar KM, Tu C, Zhang W, Cai Y (2001) A fern that hyper accumulates arsenic. Nat 409:579

Maclachalam S, Zalik S (1963) Plastid structure, chlorophyll concentration and free amino acid composition of a chlorophyll mutant of barley. Can J Bot 41:1053-1062

Mahalakshmi R, Sivapragasam C, Vanitha S (2009a) Duckweed by Genetic Programming Information and Communication Technology for Intelligent Systems. Springer, Berlin/Heidelberg, Germany, pp 401-408

Mahalakshmi R, Sivapragasam C, Vanitha S (2019b) Comparison of BOD 5 removal in water hyacinth and duckweed by genetic programming: proceedings of information and communication technology for intelligent systems

Maine MA, Duarte MV, Sune NL (2001) Cadmium uptake by floating macrophytes. Wat Res 35:2629-2634

Maran o'n E, Va'zquez I, Rodrı'guez J, Castrillo'n L, Ferna’ndez Y, Lo'pez H (2008) Treatment of coke wastewater in a sequential batch reactor (SBR) at pilot plant scale. Bioresour Technol 99:4192-4198

Maxwell K, Johnson GN (2000) Chlorophyll fluorescence a practical guide. J Experimental Botechnol 51:659-668

Nye PH, Tinker PB (1977) Solute movement in the soil root system. Blackwell Scientific Publication, University of California Press

Pandey VC (2012) Invasive species based efficient green technology for phytore-mediation of fly ash deposits. J Geochem Explor 123:13-18

Pilon-Smits E (2005) Phytoremediation. Annu Rev Plant Biol 56:15-39

Reeves RD, Baker AJ, Jaffré T, Erskine PD, Echevarria G, van der Ent A (2018) A global database for plants that hyperaccumulate metal and metalloid trace elements. New Phytol 218:407-411

Reynel-Avila HE, Mendoza-Castillo DI, Hernández-Montoya V, Bonilla-Petriciolet A (2011) Multicomponent removal of heavy metals from aqueous solution using low-cost sorbents. In: Water production and wastewaters Treatment. Editorial Nova Science Publisher

Rezania S, Ponraj M, Din MFM, Songip AR, Sairan FM, Chelliapan S (2015) The diverse applications of water hyacinth with main focus 
on sustainable energy and production for new era: an overview. Renew Sustain Energy Rev 943-954

Rezania S, Ponraj M, Talaiekhozani A, Mohamad SE, Md Din MF, Taib SM, Sabbagh F, Md Sairan F (2015b) Perspectives of phytoremediation using water hyacinth for removal of heavy metals, organic and inorganic pollutants in wastewater. J Environ Manage 163:125-133

Rezania S, Taibb SM, Md Dina MF, Dahalanc FA, Kamyaba H (2015c) Comprehensive review on phytotechnology: Heavy metals removal by diverse aquatic plants species from wastewater. J Hazard Mater 318:587-599

Roshani GA, Narayanasamy G (2010) Determination of kinetic parameters for potassium uptake by wheat at different growth stages. Int J Plant Prod 4:8033-8043

Roy S, Hanninen O (1994) Pentachlorophenol: uptake/elimination kinetics and metabolism in an aquatic plant, Eichhornia crassipes. Environ Toxicol Chem 13:763-773

Sarkar M, Rahman A, Bhoumik N (2017) Remediation of chromium and copper on water hyacinth (E. crassipes) shoot powder. Water Resour Ind 17:1-6

Scragg AH (2006) The effect of phenol on the growth of chlorella vulgaris and chlorella VT-1. Enzyme Microb Technol 39:796-799

Shi J, Xiang Z, Peng T, Li H, Huang K, Liu D, Huang T (2020) Effects of melatonin-treated to Nasturtiumo_cinale on the growth and cadmium accumulation of subsequently grown rice seedlings. Int J Environ Anal Chem

Singh N, Balomajumder C (2016) Continuous packed bed adsorption of phenol and cyanide onto modified rice husk: an experimental and modeling study. Desal Water Trea 1-15

Singh S, Melo JS, Eapen S, D'souza SF (2008) Potential of vetiver (Vetiveriazizanoides L. Nash) for phytoremediation of phenol. Ecotoxicol Environ Saf 71:671-676
Smolyakov BS, Ryzhikh AP, Bortnikova SB, Saeva OP, Chernova NY (2010) Behavior of metals ( $\mathrm{Cu}, \mathrm{Zn}$ and $\mathrm{Cd})$ in the initial stage of water system contamination: Effect of $\mathrm{pH}$ and suspended particles. App Geochem 25:1153-1161

Staib C, Lant P (2007) Thiocyanate degradation during activated sludge treatment of coke-ovens wastewater. Biochem Eng J 34:122-130

Tewes LJ, Stolpe C, Kerim A, Krämer U, Müller C (2018) Metal hyperaccumulation in the Brassicaceae species Arabidopsis halleri reduces camalexin induction after fungal pathogen attack. Environ Exp Bot 153:120-126

Trapp S, Zambrano KC, Kusk KO, Karlson U (2000) A phytotoxicity test using transpiration of willows. Arch Environ Contam Toxicol 39:154-160

Vedula RK, Dalal S, Majumder CB (2013) Bioremoval of Cyanide and Phenol from Industrial Wastewater: An Update. Bioremed J 17(4):278-293

Wilkie AC, Evans JA (2010) Aquatic plants: an opportunity feedstock in the age of bioen-ergy. Biofuels 1:311-321

Xiao-Zhang Y, Ji-Dong G, Luan L (2008) Assimilation and physiological effects of ferrocyanide on weeping willows. Ecotoxic Environ Saf 71:609-615

Yadav KK, Gupta N, Kumar A, Reece LM, Singh N, Rezania S, Khan SA (2018) Mechanistic understanding and holistic approach of phytoremediation: A review on application and future prospects. Ecol Eng 120:274-298

Publisher's Note Springer Nature remains neutral with regard to jurisdictional claims in published maps and institutional affiliations. 